\title{
Atmospheric methane uptake by tropical montane forest soils and the contribution of organic layers
}

\author{
Katrin Wolf · Heiner Flessa $\cdot$ Edzo Veldkamp
}

Received: 24 June 2011/Accepted: 8 November 2011/Published online: 30 November 2011

(C) The Author(s) 2011. This article is published with open access at Springerlink.com

\begin{abstract}
Microbial oxidation in aerobic soils is the primary biotic sink for atmospheric methane $\left(\mathrm{CH}_{4}\right)$, a powerful greenhouse gas. Although tropical forest soils are estimated to globally account for about $28 \%$ of annual soil $\mathrm{CH}_{4}$ consumption $\left(6.2 \mathrm{Tg} \mathrm{CH}_{4}\right.$ year $^{-1}$ ), limited data are available on $\mathrm{CH}_{4}$ exchange from tropical montane forests. We present the results of an extensive study on $\mathrm{CH}_{4}$ exchange from tropical montane forest soils along an elevation gradient $(1,000$, $2,000,3,000 \mathrm{~m})$ at different topographic positions (lower slope, mid-slope, ridge position) in southern Ecuador. All soils were net atmospheric $\mathrm{CH}_{4}$ sinks, with decreasing annual uptake rates from $5.9 \mathrm{~kg} \mathrm{CH}_{4}$ $\mathrm{C}$ ha $^{-1}$ year $^{-1}$ at $1,000 \mathrm{~m}$ to $0.6 \mathrm{~kg} \mathrm{CH}_{4}-\mathrm{C} \mathrm{ha}^{-1}$ year $^{-1}$ at 3,000 m. Topography had no effect on soil atmospheric $\mathrm{CH}_{4}$ uptake. We detected some unexpected factors controlling net methane fluxes: positive correlations between $\mathrm{CH}_{4}$ uptake rates, mineral nitrogen content of the mineral soil and with $\mathrm{CO}_{2}$ emissions indicated that the largest $\mathrm{CH}_{4}$ uptake corresponded with
\end{abstract}

\section{K. Wolf $(\bowtie) \cdot$ E. Veldkamp}

Büsgen Institute-Soil Science of Tropical and Subtropical Ecosystems, Georg-August University of Göttingen, Büsgenweg 2, 37077 Göttingen, Germany e-mail: kwolf@gwdg.de

\section{H. Flessa}

Johann Heinrich von Thünen-Institut, Federal Research Institute for Rural Areas, Forestry and Fisheries, Institute of Agricultural Climate Research,

Braunschweig, Germany favorable conditions for microbial activity. Furthermore, we found indications that $\mathrm{CH}_{4}$ uptake was $\mathrm{N}$ limited instead of inhibited by $\mathrm{NH}_{4}{ }^{+}$. Finally, we showed that in contrast to temperate regions, substantial high affinity methane oxidation occurred in the thick organic layers which can influence the $\mathrm{CH}_{4}$ budget of these tropical montane forest soils. Inclusion of elevation as a co-variable will improve regional estimates of methane exchange in these tropical montane forests.

Keywords Methane uptake $\cdot$ Carbon dioxide · Trace gases - Tropical montane forests . Organic layers · Elevation gradient ·

Topographic gradient - Gas diffusion barrier

\section{Introduction}

Methane $\left(\mathrm{CH}_{4}\right)$ is a trace gas with a global warming potential 21 times greater than that of carbon dioxide $\left(\mathrm{CO}_{2}\right)$ and participates in chemical reactions producing tropospheric ozone (Forster et al. 2007; Topp and Pattey 1997). Oxidation processes are the main sink of atmospheric $\mathrm{CH}_{4}$, with the reaction of hydroxylradicals $(\mathrm{OH})$ in the troposphere accounting for approximately $90 \%$ of annual $\mathrm{CH}_{4}$ removal (Prather et al. 2001). Although soils can act as sinks and sources for $\mathrm{CH}_{4}$, microbial oxidation (methanotrophy) in aerated upland soils is the primary biotic sink for atmospheric $\mathrm{CH}_{4}$ (Potter et al. 1996). Two forms of methanotrophic oxidation are known in aerated soils. 
The first, low affinity oxidation, is only found near methane sources (e.g. in peat soils and rice paddies) and is performed by methylotrophic bacteria at $\mathrm{CH}_{4}$ concentrations higher than $40 \mu 1^{-1}$ (Conrad 1996; Le Mer and Roger 2001). The second, high affinity oxidation, occurs at atmospheric $\mathrm{CH}_{4}$ concentrations and is responsible for atmospheric $\mathrm{CH}_{4}$ consumption by aerated soils (Conrad 1996).

The net $\mathrm{CH}_{4}$ exchange between soils and the atmosphere is controlled by soil physical and chemical properties that determine gas diffusivity, microbial activity and the balance between the processes of $\mathrm{CH}_{4}$ production (methanogenesis) and uptake (methanotrophy). Gas diffusivity is considered the primary regulating factor for $\mathrm{CH}_{4}$ consumption in soils, as the potential consumption of atmospheric $\mathrm{CH}_{4}$ by high affinity methanotrophs generally exceeds the rate of $\mathrm{CH}_{4}$ to diffuse from the atmosphere into the soil (Striegl 1993). Soil texture and soil moisture mainly control diffusivity in soils by regulating permeability and gas transport resistance, as $\mathrm{CH}_{4}$ diffuses $10^{4}$ times faster in air than in water (Dörr et al. 1993; Topp and Pattey 1997). Organic layers are considered to affect $\mathrm{CH}_{4}$ oxidation primarily as gas diffusion barriers because they display little, if any, $\mathrm{CH}_{4}$ oxidation capacity (Butterbach-Bahl et al. 2002a; Maurer et al. 2008; Saari et al. 1998; Steinkamp et al. 2001). The removal of the organic layer led e.g. to enhanced $\mathrm{CH}_{4}$ uptake of temperate forest soils (Brumme and Borken 1999; Saari et al. 1998). Besides substrate availability, microbial activity in soils is regulated by temperature, where increasing temperatures lead to higher microbial activity, and nutrient availability (Conrad 1996). $\mathrm{N}$ availability can indirectly affect $\mathrm{CH}_{4}$ uptake, by competition of $\mathrm{NH}_{4}^{+}$with $\mathrm{CH}_{4}$ for methane oxidizing enzymes and the blocking of enzyme functions by products of $\mathrm{NH}_{4}{ }^{+}$oxidation (Schnell and King 1994). Negative correlations between $\mathrm{CH}_{4}$ uptake rates and extractable $\mathrm{NH}_{4}{ }^{+}$or nitrification rates have been reported in tropical regions (Mosier and Delgado 1997; Veldkamp et al. 2001). Furthermore, net $\mathrm{CH}_{4}$ fluxes in soils are the result of $\mathrm{CH}_{4}$ production and $\mathrm{CH}_{4}$ oxidation which are regulated by spatial and temporal variability of anaerobic and aerobic microsites in the soil. Anaerobic microsites in upland soils may occur during wet periods or due to consumption of soil oxygen because of high microbial activity (Verchot et al. 2000). An enhanced occurrence of anaerobic microsites can turn soils from net sinks for atmospheric $\mathrm{CH}_{4}$ into net sources (Davidson et al. 2004; Keller and Reiners 1994; Keller et al. 2005).

Most tropical lowland rainforest soils are sinks for atmospheric $\mathrm{CH}_{4}$ (Kiese et al. 2003, 2008; Werner et al. 2006). Uptake of atmospheric $\mathrm{CH}_{4}$ in aerobic tropical forest soils is estimated to account for about $28 \%$ of the global annual soil consumption (6.2 $\mathrm{Tg} \mathrm{year}^{-1}$ ) (Dutaur and Verchot 2007). Montane forests cover about $9 \%$ of the tropics (FRA 2000) and the few studies that have been conducted on $\mathrm{CH}_{4}$ fluxes show that their soils are generally $\mathrm{CH}_{4}$ sinks (Delmas et al. 1992; Ishizuka et al. 2005; Kiese et al. 2008; Purbopuspito et al. 2006). However, a recent study conducted by our group in the same region as the present study showed that $\mathrm{CH}_{4}$ produced in the canopy by Bromeliads may change the source-sink balance of these ecosystems (Martinson et al. 2010). The extreme variation in elevation gradients and topography are likely to affect methane fluxes at the soil surface (e.g. increasing precipitation and decreasing temperatures at higher elevations, changes of soil moisture and the accumulation of organic matter in the organic layers). We are not aware of a study on the potential contribution of organic layers to oxidize methane in tropical montane forest soils even though thick organic layers frequently occur in these ecosystems (Edwards and Grubb 1977).

Here, we present the results of an extensive study on $\mathrm{CH}_{4}$ exchange from tropical montane forests soils along an elevation gradient from 1,000 to 3,000 $\mathrm{m}$ and along topographic gradients (lower slope, mid-slope, and ridge) in southern Ecuador. We tested the following hypotheses: (1) net uptake of atmospheric $\mathrm{CH}_{4}$ decreases with elevation due to an increasing soil moisture and a decreasing temperature, (2) net uptake of atmospheric $\mathrm{CH}_{4}$ decreases with increasing organic layer thickness, (3) net uptake of atmospheric $\mathrm{CH}_{4}$ is inhibited by high $\mathrm{N}$ availability and that (4) organic layers contribute not or only little to the uptake of atmospheric $\mathrm{CH}_{4}$ in tropical montane forests soils. We investigated soil $\mathrm{CH}_{4}$ exchange, possible biogeochemical controls, and the contribution of organic layers to the atmospheric $\mathrm{CH}_{4}$ uptake using a combination of field measurements and laboratory incubations of mineral soil and organic layers. 


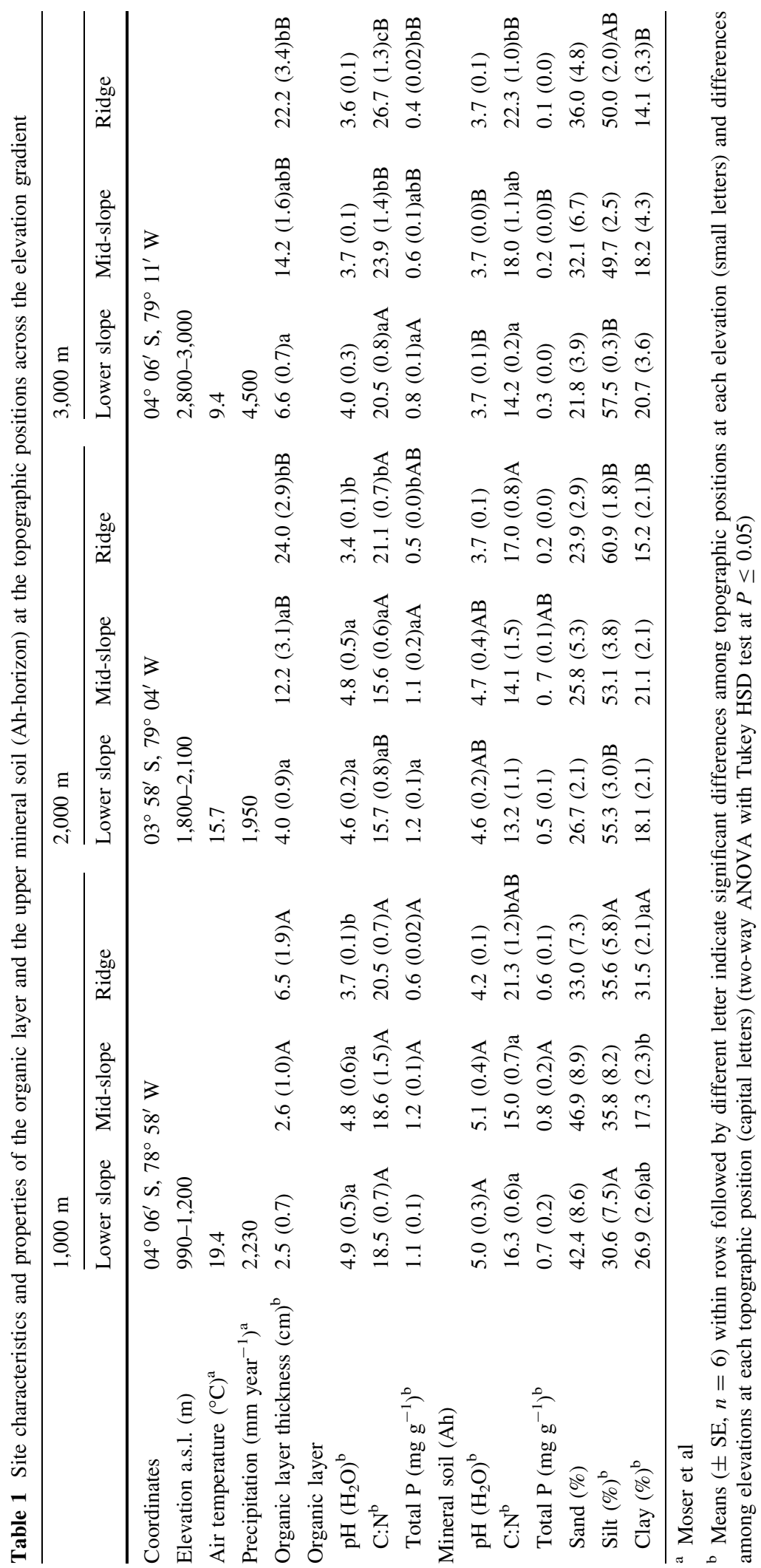




\section{Methods}

Study area

The study was carried out along an elevation gradient from 1,000 to 3,000 m within and close to Podocarpus National Park. The park is located in the Cordillera del Consuelo, which forms part of the eastern chain of the Andes in southern Ecuador. Three study sites were selected (Table 1): premontane rainforest, from 990 to $1,200 \mathrm{~m}$ a.s.l. (hereafter the ' $1,000 \mathrm{~m}$ site'), lower montane forest, from 1,800 to $2,100 \mathrm{~m}$ a.s.l. (hereafter the '2,000 $\mathrm{m}$ site') and upper montane forest, from 2,800 to $3,000 \mathrm{~m}$ a.s.l. (hereafter the ' $3000 \mathrm{~m}$ site'). At each study site $(1,000,2,000,3,000 \mathrm{~m})$ we established 18 plots at three landscape positions: lower slope, mid-slope and ridge. Annual precipitation showed little seasonality (Emck 2007). For most of the study area, Paleozoic metamorphic schist and sandstones with some quartz veins form the parent material for soil development. However, at the 1,000 m site, soil parent material of half of the plots consists of deeply weathered granitic rock of the Jurassic Zamora granitoide formation (Litherland et al. 1994). Organic layer thickness increased with elevation and from lower slope positions to ridge positions (Table 1), but displayed large spatial variation, ranging from 0 to $30 \mathrm{~cm}$ at the $1,000 \mathrm{~m}$ site, and from 0.5 to $75 \mathrm{~cm}$ at the 2,000 and 3,000 $\mathrm{m}$ sites. At the ridge positions of the 2,000 and 3,000 $\mathrm{m}$ sites and to some extend at the ridges of the $1,000 \mathrm{~m}$ site, thick organic layers led to Humic and Histic characterization of soil types. Soils at well-drained positions of the 1,000 and $2,000 \mathrm{~m}$ sites classified as Eutric or Dystric Cambisols. Soils with hydromorphic properties (Stagnic Cambisols or Planosols) were found on the ridges of the 2,000 m site and at all topographic positions of the $3,000 \mathrm{~m}$ site (Wolf et al. (2011)).

\section{Experimental design}

At each elevation we established 18 plots, six at each landscape position (lower slope, mid-slope and ridge positions). All plots were situated in mature, closedcanopy forest that was representative for the respective topographic position. In each plot we installed four chamber bases for gas exchange measurements in a random design along two orthogonal transects, in total 216 chambers (54 plots $\times 4$ chambers per plot).
Chamber bases were installed 6 months prior to the first measurements, inserting them approximately $0.02 \mathrm{~m}$ into the soil and remained in place until the end of the sampling period. We used an inserting depth of only $0.02 \mathrm{~m}$ in order to minimize root disturbance and because the dense canopy provided an efficient wind protection. Chamber lids were equipped with a Luer-Lock sampling port and a vent for pressure equilibration. Methane, soil respiration, soil moisture content, soil temperature, and soil mineral $\mathrm{N}$ were measured bi-monthly over a period of 1 year (May 2008-May 2009).

\section{Site characterization}

Soil characteristics of the plots were determined from 41 soil profiles $(0.5-1.5 \mathrm{~m})$ at the beginning of the study (2008). We dug a soil pit at each plot except for very similar plots which were located at the same site, at the same slope position and which had the same inclination. For such similar plots we sampled only one common soil pit. All together 41 soil profiles were analyzed to characterize soil properties. Bulk densities of the mineral soil and the organic layers were determined according to Blake and Hartge (1986). For chemical analysis, samples from the organic layer (as a pooled sample covering the whole depth of the organic layer) and from the Ah horizon were ovendried $\left(45^{\circ} \mathrm{C}\right.$ for 3 days), sieved and stored in plastic bags until air transported to Germany. Total carbon $\left(\mathrm{C}_{\mathrm{tot}}\right)$ and total nitrogen $\left(\mathrm{N}_{\mathrm{tot}}\right)$ were determined using ground samples and a CNS Elemental Analyzer (Elementar Vario EL, Hanau, Germany). Total P $\left(\mathrm{P}_{\text {tot }}\right)$ and total base cations were measured using Inductively Coupled Plasma-Atomic Emission Spectrometer (ICP-AES; Spectro Analytical Instruments, Kleve, Germany) after pressure digestion in $65 \% \mathrm{HNO}_{3}$. Soil $\mathrm{pH}$ was measured in a suspension of soil in $\mathrm{H}_{2} \mathrm{O}$ with 1:1 and 1:10 ratio for sieved mineral soil and organic layer, respectively. Soil texture of the Ah horizon was determined by sedimentary fractionation of the clay fraction $\left(25^{\circ} \mathrm{C}, 21 \mathrm{~h}, 30 \mathrm{~cm}\right.$ fall height $)$ following the Atterberg method after wet sieving of the sand and coarse silt fraction $(630,200,63$ and $20 \mu \mathrm{m})$ and destruction of organic matter with $30 \% \mathrm{H}_{2} \mathrm{O}_{2}$ and $\mathrm{Fe}$ oxides with $4 \% \mathrm{Na}$-Dithionite-Citrate solution (Schlichting et al. 1995). Fine and mid silt fractions (20-2 $\mu \mathrm{m}$ ) were determined by drying and weighing of the remaining material in the Atterberg Cylinders 
after the elutriation of the clay fraction. We did not separate fine and mid silt fractions. Soil moisture content, soil mineral $\mathrm{N}$, and soil temperature were determined at the depth of 0 to $0.05 \mathrm{~m}$ of the surface (organic layer or mineral soil), within one meter distance of the chamber bases concomitantly with every gas sampling. We expressed soil moisture as gravimetric moisture content. Soil mineral N (ammonia $\left(\mathrm{NH}_{4}{ }^{+}\right)$and nitrate $\left(\mathrm{NO}_{3}{ }^{-}\right)$) was determined on a composite soil sample, which consisted of four subsamples per plot. In the field, part of the composite sample was added to a polyethylene bottle containing $150 \mathrm{ml}$ of 0.5 molar potassium sulfate $\left(\mathrm{K}_{2} \mathrm{SO}_{4}\right)$ solution. The remaining part of each sample was stored in a plastic bag for determination of gravimetric moisture content in the laboratory after drying for $24 \mathrm{~h}$ at $105^{\circ} \mathrm{C}$. Extraction of soil mineral $\mathrm{N}$ was finished within $12 \mathrm{~h}$ after field sampling to avoid shifts in $\mathrm{NH}_{4}{ }^{+}$and $\mathrm{NO}_{3}{ }^{-}$concentrations in the soil over time (Arnold et al. 2008). Extracts were filtered through filter papers $(4 \mu \mathrm{m}$ nominal pore size $)$ after $1 \mathrm{~h}$ of agitation, and frozen immediately after a drop of chloroform was added to prevent further $\mathrm{N}$ turnover. Samples remained frozen during transportation by air to Germany, where analysis was conducted. Ammonium and $\mathrm{NO}_{3}{ }^{-}$concentrations of the extracts were analyzed using a continuous flow injection colorimeter (Cenco/Skalar Instruments, Breda, Netherlands) (Arnold et al. 2009).

Field measurement of net $\mathrm{CH}_{4}$ exchange and soil respiration

We measured net exchange rates of $\mathrm{CH}_{4}$ and $\mathrm{CO}_{2}$ bimonthly and once a day over a time period of 1 year (May 2008-May 2009). We used static closed chambers with a base area of $0.044 \mathrm{~m}^{2}$ and a closed chamber volume of 131 . Gas samples were taken 2 , 14, 26, and 38 min following chamber closure using pre-evacuated glass containers $(60 \mathrm{ml})$. Pressure was checked with a manometer during sampling to assure that containers had been evacuated properly and were filled to atmospheric pressure. Gas samples were analyzed within $48 \mathrm{~h}$ following sampling using a gas chromatograph (Shimadzu GC-14B, Duisburg, Germany) equipped with a flame ionization detector (FID) and an electron capture detector (ECD) combined with an autosampler (Loftfield et al. 1997). Gas concentrations were calculated by comparing integrated peak areas of samples with four standard gases $\left(1.5,2.0,10\right.$ and $20 \mu \mathrm{l}^{-1}$ standard concentrations of $\mathrm{CH}_{4}$; and 350, 700, 1500, $5000 \mu \mathrm{l}^{-1}$ standard concentrations of $\mathrm{CO}_{2}$; Deuste Steiniger $\mathrm{GmbH}$, Mühlhausen, Germany). Methane exchange rates were calculated from the linear change of $\mathrm{CH}_{4}$ concentration in the chamber air over time, while $\mathrm{CO}_{2}$ emissions were calculated by fitting both linear and quadratic regression models if $\mathrm{CO}_{2}$ concentrations increased asymptotically (Wagner et al. 1997). Positive flux rates represent net emissions and negative values represent net uptake rates by soils. Based on the Akaike Information Criterion the quadratic model was found to be statistically more adequate and therefore applied in about $50 \%$ of the cases. By applying this data screening and model fitting, we minimized underestimations of $\mathrm{CO}_{2}$ emissions that may have occurred by using linear models uncritically with static chamber flux data (Livingston et al. 2006). Due to the low seasonality of gas fluxes, annual fluxes were approximated from the yearly average of the six bi-monthly measurements, assuming constant fluxes per day.

Potential uptake of atmospheric $\mathrm{CH}_{4}$ and soil respiration at different soil depths

To determine the potential uptake of atmospheric $\mathrm{CH}_{4}$ and soil respiration at different soil depths and to determine the influence of temperature on gas flux rates, we conducted a laboratory incubation experiment. Undisturbed samples from mineral soils and organic layers were taken from selected soil profiles using stainless steel cores $\left(100 \mathrm{~cm}^{3}\right)$. We sampled 12 soil profiles of the mineral soil at the lower slope positions of the $1,000 \mathrm{~m}$ site, where no organic layer was present. We sampled six mineral soil profiles from soils on deeply weathered granite and six from young, shallow soils over schist. The mineral soil profiles consist of samples from four different soil depths: 0-5, 5-10, 10-15 and 15-20 cm. Furthermore, we sampled 15 organic layer profiles from the ridge positions of the three elevations. The organic layers profiles were sampled in 5-cm depth intervals from the surface to the mineral soil and include two depth of the underlying mineral soil $(0-5$ and $5-10 \mathrm{~cm})$. We sampled three organic layer profiles over weathered granite at $1,000 \mathrm{~m}$, seven organic layer profiles at 2,000 m and five organic layer profiles at 3,000 m. Additionally, 
we took disturbed samples of each profile depth to determine gravimetric moisture content after drying for $24 \mathrm{~h}$ at $105^{\circ} \mathrm{C}$. The undisturbed samples were transported to the laboratory of the Technical University in Loja and were incubated the next day.

We incubated soil cores at field moisture and two different temperatures $\left(15\right.$ and $\left.25^{\circ} \mathrm{C}\right)$ under ambient air in closed glass flasks (0.4 1) with a septum sampling port. Soil cores were pre-incubated for $24 \mathrm{~h}$ at the respective incubation temperature. If necessary, soil moisture was re-adjusted to the initial moisture content prior to incubation, by weighing soil cores and adding distilled water. After $90 \mathrm{~min}$ of incubation, a gas sample $(10 \mathrm{ml})$ was taken from the headspace of the flask through a septum with a gas tight syringe (SEG International, Ringwood, Australia), and the concentration of $\mathrm{CH}_{4}$ and $\mathrm{CO}_{2}$ was measured with the gas chromatograph described above. Methane fluxes and $\mathrm{CO}_{2}$ emissions were calculated as the difference of the gas concentration measured after the incubation of $90 \mathrm{~min}\left(\mathrm{~T}_{1}\right)$ and the initial concentration in fresh air before the incubation flask was closed ( $T_{0}$ concentration, fresh ambient air). The gas fluxes were related to the soil core surface area $\left(24 \mathrm{~cm}^{2}\right)$ and expressed as flux per square meter. As $\mathrm{CH}_{4}$ uptake activity is strongly controlled by substrate availability, this procedure probably resulted in an underestimation of the $\mathrm{CH} 4$ uptake, however we were mainly interested in the relative differences in uptake activity between soil cores at different depths, for which this procedure was sufficient. After incubation, soil material was dried at $45^{\circ} \mathrm{C}$, ground and analyzed for $\mathrm{pH}, \mathrm{C}_{\mathrm{tot}}, \mathrm{N}_{\mathrm{tot}}, \mathrm{P}_{\text {tot }}$ and base cations as described for the soil samples above.

$\mathrm{CH}_{4}$ concentration in soil air of organic layers

To determine in situ soil air $\mathrm{CH}_{4}$ concentration at different organic layer depths, we sampled soil air in $10-\mathrm{cm}$ steps from the mineral soil to the surface at the same sampling points at 2,000 and 3,000 m selected for the incubation experiment. We measured three profiles per sampling point using a steel tube $\left(1.8^{\prime \prime}\right.$, 60-80 cm, Alltech, Unterhaching) and pre-evacuated glass containers $(20 \mathrm{ml})$, after evacuating the tubing with a syringe. Gas concentrations were measured using the gas chromatograph described above. Measurements were carried out during a relatively dry period (October-November 2010) and during a wet period (February-March 2011).

Statistical analyses

Statistical analysis of data from the field measurements was carried out on the plot mean of trace gas fluxes (average of four chambers). Linear mixed effects models (LME) were applied to test the effect of:

(1) Elevation and topography on time series data (i.e. bi-monthly measurements of trace gas fluxes, soil moisture and soil mineral $\mathrm{N}$ ), with elevation and topographic position as fixed effects, and replicate plots nested in time as a random effect.

(2) Continuous variables (soil moisture and soil mineral $\mathrm{N}$ ) on temporal variance of the gas fluxes, with the continuous variable as fixed effect and replicate plots nested in time as a random factor.

(3) Continuous variables on the spatial variability of annual gas fluxes, including topographic positions nested into the elevations as spatial random factor.

(4) Temperature and soil texture on trace gas fluxes of the incubated samples, with profile depth as a random factor.

(5) Wet and dry season, soil depth and elevation on $\mathrm{CH}_{4}$ soil air concentrations, including the hierarchical sampling structure as a spatial random factor.

(6) We used LME for time series data because they account for temporal correlation among observations on the same experimental unit (Piepho et al. 2004) and we used LME to test spatial correlations to account for the hierarchical study design by including different error variances of the different spatial scales (Crawley 2009). LME were tested for autocorrelation effects by including a first order autoregressive structure and for heteroscedasticity of residual variance by including variance functions (Bliese and Ployhart 2002). Model residuals were tested for normal distribution and data was transformed if necessary. For testing the elevation and topography effects on data that were measured once (i.e. soil characteristics) we used two-way analysis of 
variance (ANOVA). The relationships among soil characteristics and annual trace gas fluxes were assessed by linear regression on the means of six plots for each topographic position $(n=9$; 3 topographic positions of three elevations). The effects of soil depth on trace gas fluxes were tested using one-way ANOVA. For multiple comparison after LME and ANOVA Tukey HSD test was applied. Correlations of trace gas fluxes from the incubated samples with continuous variables (i.e. carbon concentrations) were examined using generalized least square models (GLS) on the elevation mean of each profile depth. GLS models were tested for autocorrelation effects of profile depth by including a spherical correlation structure. Means with \pm 1 standard error are given in the text. Effects were accepted as statistically significant if $P \leq 0.05$. Analyses were conducted using R version 2.10.1 (R Development Core Team 2009) and STATISTICA Service Pack 8 (StatSoft Inc., Tusla, USA).

\section{Results}

Soil net $\mathrm{CH}_{4}$ fluxes along elevation and topographic gradients

Atmospheric $\mathrm{CH}_{4}$ uptake of the soil decreased with increasing elevation $(P<0.001)$, whereas topography did not affect atmospheric $\mathrm{CH}_{4}$ uptake. Soil net $\mathrm{CH}_{4}$ fluxes did not display a clear seasonality (Fig. 1) and soils of all elevations and topographic positions were net sinks for atmospheric $\mathrm{CH}_{4}$ with annual mean uptake rates ranging from $0.6 \pm 1.2 \mathrm{~kg} \mathrm{CH}_{4}-\mathrm{C} \mathrm{ha}^{-1}$ year $^{-1}$ at $3,000 \mathrm{~m}$ to $5.9 \pm 1.0 \mathrm{~kg} \mathrm{CH}_{4}-\mathrm{C} \mathrm{ha}^{-1}$ year $^{-1}$ at $1,000 \mathrm{~m}$ (Table 2). Positive $\mathrm{CH}_{4}$ fluxes (emissions) occurred in $5.3 \%$ of all measurements and increased with elevation from $2.1 \%$ at $1,000 \mathrm{~m}$ and $5.2 \%$ at $2,000 \mathrm{~m}$ to $8.9 \%$ at $3,000 \mathrm{~m}$. Variability of fluxes was highest at the lower slope position at 3,000 $\mathrm{m}$ where $22 \%$ of $\mathrm{CH}_{4}$ fluxes measured were positive. We found no effect of different soil parent material (granite vs. schist) on net atmospheric $\mathrm{CH}_{4}$ uptake rates $(P=0.4)$ (Table 3). To determine the effect of elevation and
Fig. 1 Annual course of soil net $\mathrm{CH}_{4}$ exchange rates and gravimetric soil moisture (means $\pm \mathrm{SE}$, $n=6$ ) of the three topographic positions (black downward triangles lower slope, black circles midslope, black upward triangles ridge) across the elevation gradient $(1,000$, 2,000, 3,000 m). Negative values represent $\mathrm{CH}_{4}$ uptake rates

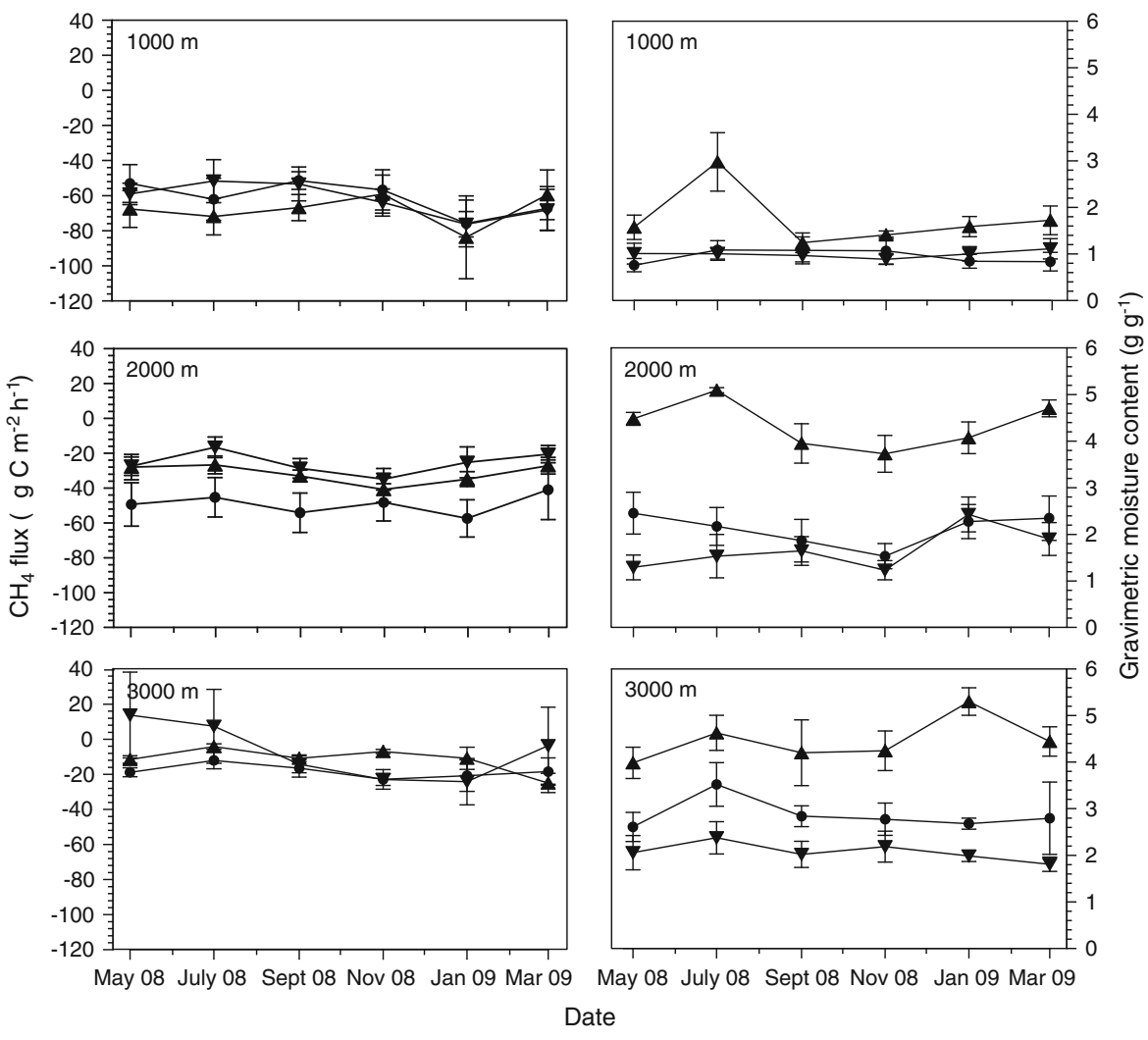




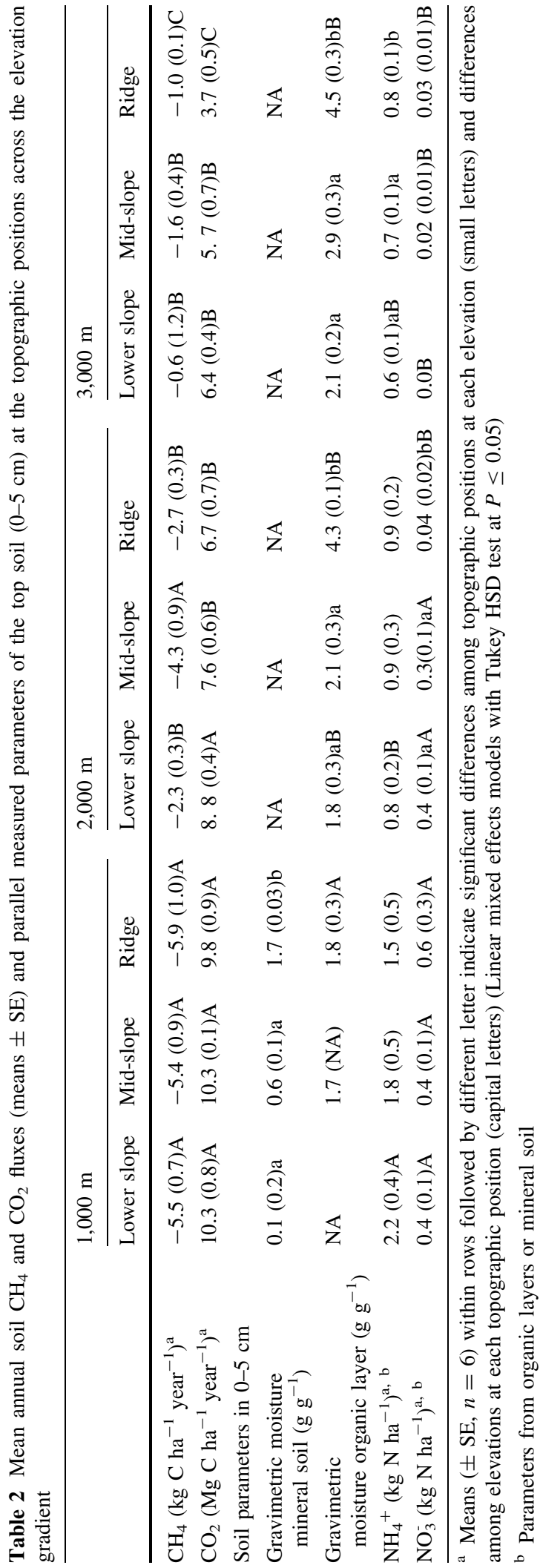

slope position on soil moisture in the top $0.05 \mathrm{~m}$ of the soil we separated results from the organic layer and the mineral soil. Gravimetric moisture content of mineral soils without organic layer, which were only found at the 1,000 $\mathrm{m}$ site, was lowest at the mid-slope position and highest at the ridges $(P=0.003)$. Gravimetric soil moisture in the top $0.05 \mathrm{~m}$ of the organic layers increased with elevation $(P<0.001)$ and from the lower slope positions to the ridges at 2,000 and 3,000 m $(P<0.001)$. We did not detect a relationship between bi-monthly measured net $\mathrm{CH}_{4}$ flux rates and soil moisture across elevations and topographic positions, neither in mineral soil nor in the organic layer. In addition, we found no significant correlation between the annual $\mathrm{CH}_{4}$ uptake and the mean soil moisture content (data not shown).

Atmospheric $\mathrm{CH}_{4}$ uptake of the soil increased with increasing soil temperature along the elevation gradient $\left(P<0.001, R^{2}=0.89\right), \mathrm{NO}_{3}{ }^{-}$content $(P<0.001$, $\left.R^{2}=0.72\right)$ and $\mathrm{NH}_{4}{ }^{+}$content $\left(P<0.002, R^{2}=0.72\right)$ of the top $0.05 \mathrm{~m}$ (mineral soil or organic layer) and with increasing $\mathrm{P}_{(\text {tot })}\left(P<0.001, R^{2}=0.66\right)$ and $\mathrm{pH}$ value of the upper mineral soil $\left(P=0.02, R^{2}=0.51\right)$. Smaller scale soil temperature changes within the elevation levels, organic layer thickness, $\mathrm{P}_{\text {tot }}, \mathrm{C}: \mathrm{N}$ ratios and the $\mathrm{pH}$ value of the organic layer did not affect atmospheric $\mathrm{CH}_{4}$ uptake. Annual $\mathrm{CO}_{2}$ emissions and annual $\mathrm{CH}_{4}$ uptake by soils with and without organic layers were correlated positively across all elevations $(P<0.01$, $R^{2}=0.66$, Fig. 5a). When considering only gas fluxes from the soils covered by an organic layer, this correlation was even stronger $\left(P=0.02, R^{2}=0.74\right)$, while the correlation in mineral soils without organic layer was not significant $\left(P=0.13, R^{2}=0.13\right)$.

Potential uptake of atmospheric $\mathrm{CH}_{4}$ at different soil depths

All incubated, undisturbed samples from the mineral soil profiles (profiles of the $1,000 \mathrm{~m}$ site, which had no organic layer) were net sinks for atmospheric methane (Fig. 2). Methane uptake rates ranged from 3.5 to $60.5 \mu \mathrm{g} \mathrm{CH}_{4}-\mathrm{C} \mathrm{m}^{-2} \mathrm{~h}^{-1}$ with the highest uptake rate of atmospheric $\mathrm{CH}_{4}$ at a soil depth of 5-10 $\mathrm{cm}(P=0.05)$. The incubated mineral soil profiles from the coarse textured granite substrate displayed a higher potential uptake of atmospheric $\mathrm{CH}_{4}$ than the profiles from the fine textured schist substrate $(P<0.001)$ (Fig. 2). Incubated organic layer samples generally acted as sinks for 
Table 3 Soil characteristics and annual flux rates of $\mathrm{CH}_{4}$ and $\mathrm{CO}_{2}$ (means and SE) of soils from two substrates (schist, granite) of the topographic positions at $1,000 \mathrm{~m}$

\begin{tabular}{|c|c|c|c|c|c|c|}
\hline & \multicolumn{2}{|l|}{ Lower slope } & \multicolumn{2}{|l|}{ Mid-slope } & \multicolumn{2}{|l|}{ Ridge } \\
\hline & Schist & Granite & Schist & Granite & Schist & Granite \\
\hline Sand $(\%)^{\mathrm{a}, \mathrm{c}}$ & $24.22(2.36) \mathrm{a}$ & $60.66(5.25) \mathrm{b}$ & $27.44(1.43) \mathrm{a}$ & $66.26(3.92) b$ & $16.73(1.72) \mathrm{a}$ & $49.16(0.87) \mathrm{b}$ \\
\hline Silt $(\%)^{\mathrm{a}, \mathrm{c}}$ & $47.05(3.84) \mathrm{a}$ & $14.20(0.04) \mathrm{b}$ & $53.98(1.04) \mathrm{a}$ & $17.67(1.73) \mathrm{b}$ & $48.05(0.99) \mathrm{a}$ & $23.09(3.47) b$ \\
\hline Clay $(\%)^{\mathrm{a}, \mathrm{c}}$ & $28.73(1.48)$ & $25.14(5.29)$ & $18.58(2.19) \mathrm{a}$ & $16.07(4.43) \mathrm{a}$ & $35.23(0.73) \mathrm{a}$ & $27.75(2.60) b$ \\
\hline $\mathrm{pH}\left(\mathrm{H}_{2} \mathrm{O}\right)^{\mathrm{a}, \mathrm{c}}$ & $5.4(0.2)$ & $4.5(0.4)$ & $5.9(0.3) \mathrm{a}$ & $4.3(0.3) \mathrm{b}$ & $3.9(0.1) \mathrm{a}$ & $4.5(0.1) \mathrm{b}$ \\
\hline $\mathrm{C}: \mathrm{N}^{\mathrm{a}, \mathrm{c}}$ & $16.3(0.6)$ & $16.4(1.2)$ & $14.5(1.5)$ & $15.6(0.2)$ & $19.0(0.9) \mathrm{a}$ & $23.7(0.8) \mathrm{b}$ \\
\hline Total P $\left(\mathrm{mg} \mathrm{g}^{-1}\right)^{\mathrm{a}, \mathrm{c}}$ & $1.1(0.1) \mathrm{a}$ & $0.3(0.02) b$ & $1.4(0.2) \mathrm{a}$ & $0.3(0.1) \mathrm{b}$ & $0.8(0.04) \mathrm{a}$ & $0.4(0.1) \mathrm{b}$ \\
\hline $\mathrm{NH}_{4}^{+}\left(\mathrm{kg} \mathrm{N} \mathrm{ha}^{-1}\right)^{\mathrm{b}, \mathrm{d}}$ & $2.8(0.6)$ & $1.5(0.2)$ & $1.0(0.4)$ & $2.7(0.3)$ & $2.7(0.2)$ & $0.4(0.1)$ \\
\hline $\mathrm{NO}_{3}^{-}\left(\mathrm{kg} \mathrm{N} \mathrm{ha}^{-1}\right)^{\mathrm{b}, \mathrm{d}}$ & $0.4(0.2)$ & $0.3(0.03)$ & $0.2(0.04)$ & $0.5(0.2)$ & $1.1(0.3) \mathrm{a}$ & $0.01(0.01) b$ \\
\hline $\mathrm{CH}_{4}\left(\mathrm{~kg} \mathrm{C} \mathrm{ha}^{-1} \text { year }^{-1}\right)^{\mathrm{b}}$ & $-5.0(0.7)$ & $-6.0(1.4)$ & $-5.1(1.3)$ & $-5.6(1.5)$ & $-8.0(0.5) \mathrm{a}$ & $-3.8(0.8) \mathrm{b}$ \\
\hline $\mathrm{CO}_{2}\left(\mathrm{Mg} \mathrm{C} \mathrm{ha}{ }^{-1} \text { year }^{-1}\right)^{\mathrm{b}}$ & $10.1(03)$ & $10.4(1.6)$ & $8.7(0.3)$ & $11.8(2.7)$ & $11.4(0.5)$ & $8.25(1.2)$ \\
\hline
\end{tabular}

${ }^{a}$ Means ( \pm SE, $n=3$ ) within rows followed by different letter indicate significant differences among the substrates (small letters) (one-way ANOVA at $P \leq 0.05$ )

b Means ( \pm SE, $n=3$ ) within rows followed by different letter indicate significant differences among the substrates (small letters) (Linear mixed effects models for time series data at $P \leq 0.05$ )

c Parameters were taken from the Ah horizon

${ }^{\mathrm{d}}$ Parameters were taken from the top $5 \mathrm{~cm}$ of the soil (including mineral soil or organic layer)

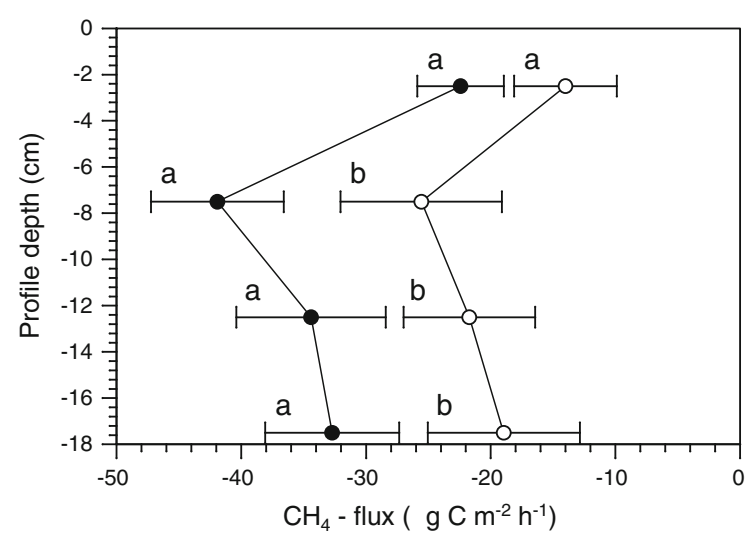

Fig. 2 Mean $\mathrm{CH}_{4}$ uptake rates of undisturbed field moist-soil samples at different depths of the mineral soil profiles, which had no organic layer in schist (open symbols) and granite (black symbols) material at $1,000 \mathrm{~m}$, incubated at $25^{\circ} \mathrm{C}$ in the laboratory. Means $( \pm \mathrm{SE}, n=6)$ within one depth followed by different letter indicate significant differences among the substrates (Kruskal-Wallis-test at $P \leq 0.05$ )

atmospheric $\mathrm{CH}_{4}$, except for the samples from the top $5 \mathrm{~cm}$, which contained mainly roots and fresh plant residues and emitted $\mathrm{CH}_{4}$ in $65 \%$ of the cases. All samples of the uppermost $0-5 \mathrm{~cm}$ of the organic layer at the $1,000 \mathrm{~m}$ and the $3,000 \mathrm{~m}$ sites emitted methane, while at the $2,000 \mathrm{~m}$ site only two of the seven uppermost profile samples emitted methane (Fig. 3). The incubated organic material from the $1,000 \mathrm{~m}$ site showed a potential $\mathrm{CH}_{4}$ uptake ranging from -0.2 to $-29.7 \mu \mathrm{g} \mathrm{CH}_{4}-\mathrm{C} \mathrm{m}^{-2} \mathrm{~h}^{-1}$. The potential $\mathrm{CH}_{4}$ exchange in the organic material from $2,000 \mathrm{~m}$ ranged from +3.1 (emission!) to $-55.8 \mu \mathrm{g} \mathrm{CH}_{4}-\mathrm{C} \mathrm{m}^{-2} \mathrm{~h}^{-1}$ and from +12.9 to $-54.5 \mu \mathrm{g} \mathrm{CH}_{4}-\mathrm{C} \mathrm{m}^{-2} \mathrm{~h}^{-1}$ in the organic material from $3,000 \mathrm{~m}$. Potential $\mathrm{CH}_{4}$ uptake of atmospheric $\mathrm{CH}_{4}$ in the mineral soil underlying the organic layers was higher at $1,000 \mathrm{~m}$ than at 2,000 or $3000 \mathrm{~m}(P<0.01)$, with uptake rates ranging from 7.5 to $70.0 \mu \mathrm{g} \mathrm{CH}_{4}-\mathrm{C} \mathrm{m}^{-2} \mathrm{~h}^{-1}$ at $1,000 \mathrm{~m}$, from 0.8 to $24.4 \mu \mathrm{g} \mathrm{CH}_{4}-\mathrm{C} \mathrm{m}^{-2} \mathrm{~h}^{-1}$ at $2,000 \mathrm{~m}$ and from -3.4 to $33.4 \mu \mathrm{g} \mathrm{CH}_{4}-\mathrm{C} \mathrm{m}^{-2} \mathrm{~h}^{-1}$ at $3,000 \mathrm{~m}$. We found a clear stratification of the potential atmospheric $\mathrm{CH}_{4}$ uptake rates within the sampled organic layer profiles. The $\mathrm{CH}_{4}$ uptake rates in the organic layer profiles from all elevations increased with increasing profile depth ( $P<0.00$, Fig. 3). At the $1,000 \mathrm{~m}$ site, potential $\mathrm{CH}_{4}$ uptake of the underlying mineral soil was higher than the organic material ( $P \leq 0.05$, Fig. 3a). At the $2,000 \mathrm{~m}$ and the $3,000 \mathrm{~m}$ sites potential atmospheric $\mathrm{CH}_{4}$ uptake was largest at the deepest organic layer overlying the mineral soil (Fig. 3b, c). Organic layer thickness did not affect the potential atmospheric $\mathrm{CH}_{4}$ uptake of the underlying mineral soil. 

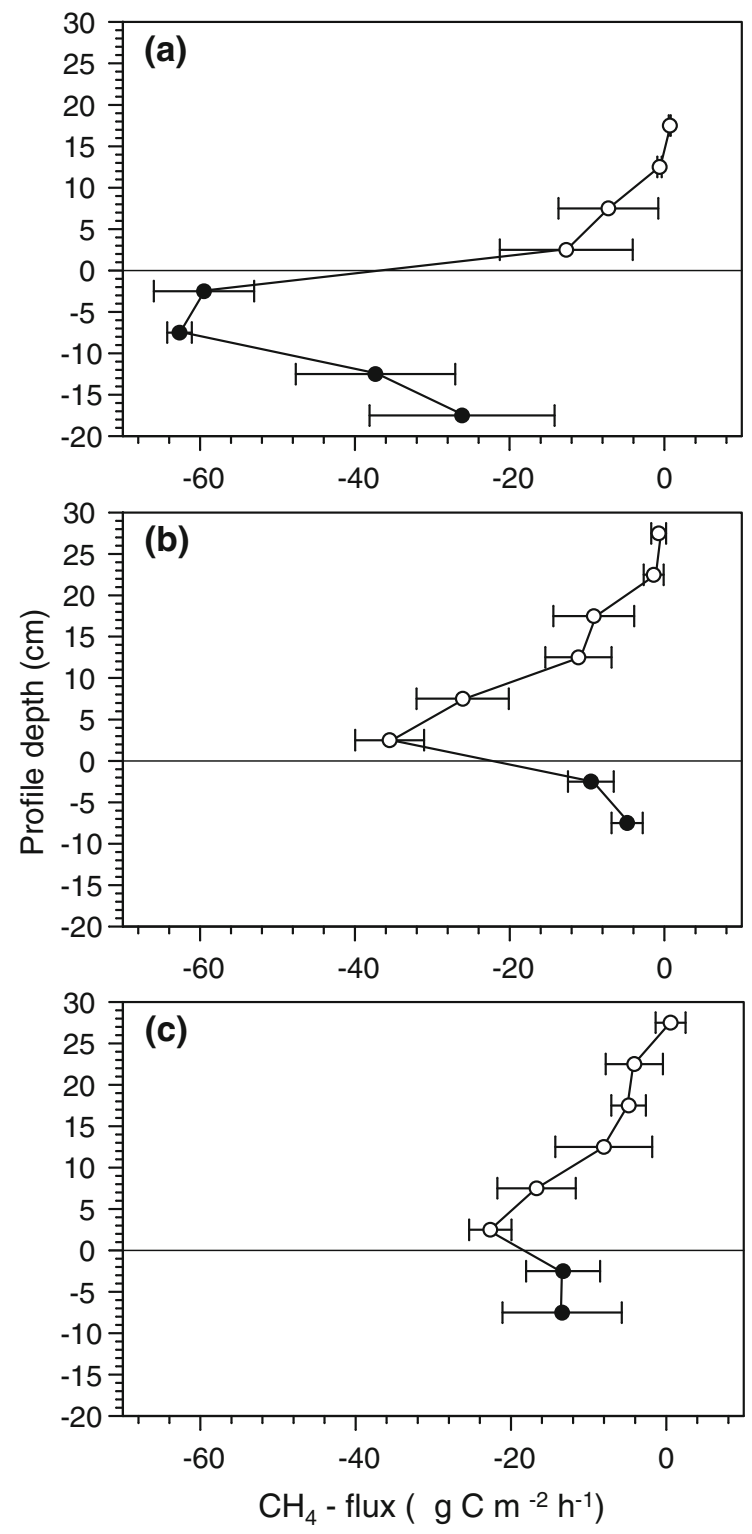

Fig. 3 Mean $\mathrm{CH}_{4}$ fluxes ( $\pm \mathrm{SE}$ ) of undisturbed, field-moist soil samples from different depths of the organic layer (open symbols) and the mineral soil (black symbols) incubated at $25^{\circ} \mathrm{C}$ in the laboratory. The samples were taken from a the $1,000 \mathrm{~m}$ site $(n=3), \mathbf{b}$ the $2,000 \mathrm{~m}$ site $(n=7)$ and $\mathbf{c}$ the $3,000 \mathrm{~m}$ site $(n=5)$

Carbon dioxide emissions from the incubated mineral soil and organic layer profiles were largest in the top soil samples, ranging from 31.1 to $68.2 \mathrm{mg}$ $\mathrm{CO}_{2}-\mathrm{C} \mathrm{m}^{-2} \mathrm{~h}^{-1}$ in the mineral soil and from 28.9 to $140.9 \mathrm{mg} \mathrm{CO}_{2}-\mathrm{C} \mathrm{m}^{-2} \mathrm{~h}^{-1}$ in the organic layer. Soil respiration decreased with soil depth of all profiles (data not shown). Temperature manipulation affected soil respiration from samples of the organic layer from all elevations $(P<0.001)$, whereas it did not affect soil respiration of the mineral soil samples $(P=0.2)$. A temperature increase from 15 to $25^{\circ} \mathrm{C}$ resulted in a doubling of the $\mathrm{CO}_{2}$ emissions rates from samples of the organic layer as shown by the doubling of the slope of the regression function (Fig. 4a). Temperature manipulation did neither affect $\mathrm{CH}_{4}$ uptake rates of samples from the organic layer profiles during the incubation (Fig. 4b), nor did it affect the $\mathrm{CH}_{4}$ uptake rates of the mineral soil profiles (data not shown).

Throughout the elevations, potential $\mathrm{CH}_{4}$ uptake of the incubated mineral soil profiles and organic layer profiles increased with decreasing $\mathrm{CO}_{2}$ emissions $\left(P<0.001, R^{2}=0.45\right.$, Fig. $\left.5 \mathrm{~b}\right)$. Throughout the elevation gradient, potential atmospheric $\mathrm{CH}_{4}$ uptake of the incubated organic material did not correlate with $\mathrm{C}_{\text {tot }}$ content, cation concentration, gravimetric moisture content, or $\mathrm{pH}$-values. However, potential $\mathrm{CH}_{4}$ uptake of organic material from the $1,000 \mathrm{~m}$ site correlated positively with $\mathrm{P}_{\text {tot }}$ content of the organic material $\left(P=0.03, R^{2}=0.90\right)$. In contrast, potential $\mathrm{CH}_{4}$ uptake of organic material of the 2,000 $\mathrm{m}$ site increased with decreasing $\mathrm{C}_{\mathrm{tot}}$ content $\left(P=0.04 ; R^{2}=0.62\right)$, calcium $\left(\mathrm{Ca}^{2+}, P=0.01 ; R^{2}=0.78\right)$ and magnesium $\left(\mathrm{Mg}^{2+}, P=0.01 ; R^{2}=0.78\right)$ concentrations and $\mathrm{pH}-$ values $\left(P<0.01 ; R^{2}=0.91\right)$ of the organic material.

$\mathrm{CH}_{4}$ concentrations in the soil air of organic layers

In situ methane concentration in the soil air decreased with soil depth $(P<0.0001$ for both elevations), both during wet and dry periods, with lowest $\mathrm{CH}_{4}$ concentrations above the mineral soil (Fig. 6). Methane concentrations were higher during the dry period measurements compared to the wet period measurements $(P<0.0001$ for both elevations) (Fig. 6). Elevation did not affect $\mathrm{CH}_{4}$ concentration in the soil air of the organic layers neither during the wet nor during the dry period. $\mathrm{CH}_{4}$ concentration in soil air was always lower than the atmospheric concentration and there was no evidence of in situ net production of $\mathrm{CH}_{4}$ within the soil profile.

\section{Discussion}

Net exchange of $\mathrm{CH}_{4}$ under field conditions

Annual $\mathrm{CH}_{4}$ uptake rates under field conditions at the 2,000 and 3,000 $\mathrm{m}$ sites were comparable to those 


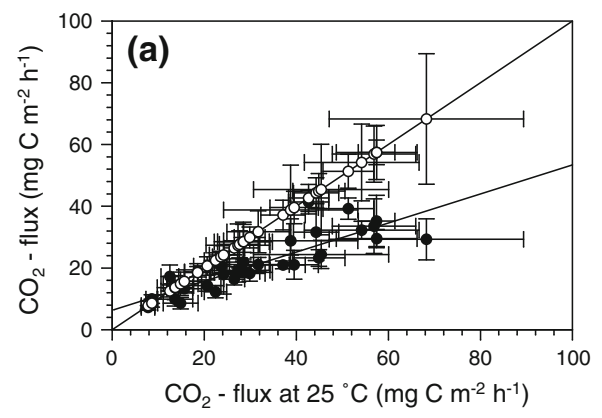

Fig. 4 Relation between mean $( \pm \mathrm{SE})$ trace gas fluxes of undisturbed, field-moist samples of the mean organic layer profile from each elevation (including the underlying mineral soil) incubated at $25^{\circ} \mathrm{C}$ (open symbols) and $15^{\circ} \mathrm{C}$ (black

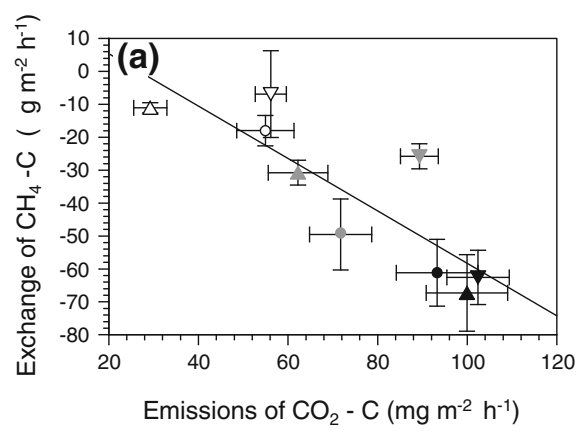

Fig. 5 Relation between soil $\mathrm{CO}_{2}$ emission rates and soil $\mathrm{CH}_{4}$ uptake rates (means $\pm \mathrm{SE}$ ) for a flux rates measured in the field at different topographic positions (black downward triangles lower slope, black circles mid-slope, black upward triangles ridge) across the elevation gradient (black: 1,000 m; full grey: $2,000 \mathrm{~m}$; open: $3,000 \mathrm{~m})(y=-21.38+0.80 \times x, n=9$, $P=0.005, R^{2}=0.66$ ), and for $\mathbf{b}$ undisturbed, field-moist soil

reported for tropical montane forest soils at comparable elevation in Indonesia $\left(1.5\right.$ and $3.3 \mathrm{~kg} \mathrm{CH}_{4}-\mathrm{C}$ $\mathrm{ha}^{-1}$ year $^{-1}$ ) (Ishizuka et al. 2005; Purbopuspito et al. 2006). Annual $\mathrm{CH}_{4}$ fluxes at the $1,000 \mathrm{~m}$ site were larger than previously reported for other premontane forests in Africa (Delmas et al. 1992), Australia (Kiese et al. 2008), Indonesia (Purbopuspito et al. 2006) and China (Werner et al. 2006) and were also larger than those reported from lowland forests in Costa Rica (Keller and Reiners 1994; Reiners et al. 1998) and Brazil (Keller et al. 2005). The 5.4-5.9 $\mathrm{kg} \mathrm{CH}_{4}-$ $\mathrm{C} \mathrm{ha}{ }^{-1}$ year $^{-1} \mathrm{CH}_{4}$ uptake rates at our $1,000 \mathrm{~m}$ site were also on the high end of the methane consumption ranges for temperate ecosystems (Fiedler et al. 2005; Smith et al. 2000). Dutaur and Verchot (Dutaur and Verchot 2007), gave an estimate of $4.3 \mathrm{~kg} \mathrm{CH}_{4}$ $\mathrm{C} \mathrm{ha}{ }^{-1}$ year $^{-1}$ for the temperate forest biome.

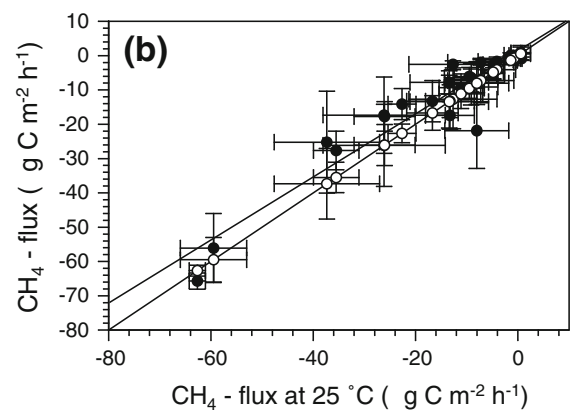

symbols $)$ for a $\mathrm{CO}_{2}$ fluxes $(y=5.5+0.5 \times x, \quad n=24$, $\left.\mathrm{P}<0.001, R^{2}=0.90\right)$ and b $\mathrm{CH}_{4}$ fluxes $(y=-1.4+0.9 \times$ $\left.x, n=24, \mathrm{P}<0.001, R^{2}=0.85\right)$

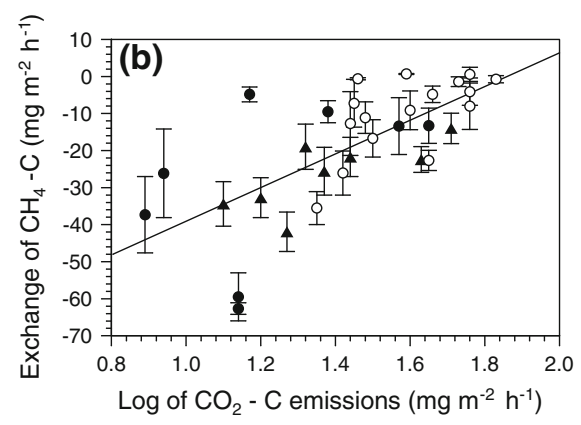

samples at different depths of the organic material (open symbols) and the mineral soil (black symbols), incubated at $25^{\circ} \mathrm{C}$ in the laboratory $(y=-84.49+45.42 \times x, n=32$, $\left.P<0.001, R^{2}=0.45\right)$. Mineral soil with overlying organic layer black circles, mineral soil without overlying organic layer black triangles

Both the increased incidence of net $\mathrm{CH}_{4}$ emission rates with increasing elevation and a general decrease in $\mathrm{CH}_{4}$ uptake rates resulted in decreased annual net $\mathrm{CH}_{4}$ uptake with elevation. This trend was mirrored by the maximum $\mathrm{CH}_{4}$ uptake rates measured for the incubated soil samples and by the less pronounced decline of soil air $\mathrm{CH}_{4}$ concentrations in the organic layers at the drier $3,000 \mathrm{~m}$ site. The lack of influence of slope position on $\mathrm{CH}_{4}$ uptake that we detected supports results from forest sites in Costa Rica where no differences in $\mathrm{CH}_{4}$ uptake between topographic positions was detected (Reiners et al. 1998). Furthermore, we found no evidence that seasonal waterlogging turned net methane-oxidizing tropical forest soils into net $\mathrm{CH}_{4}$ sources as reported for seasonal lowland rain forests in Brazil (Davidson et al. 2004; Verchot et al. 2000). Seasonal variation in soil water 


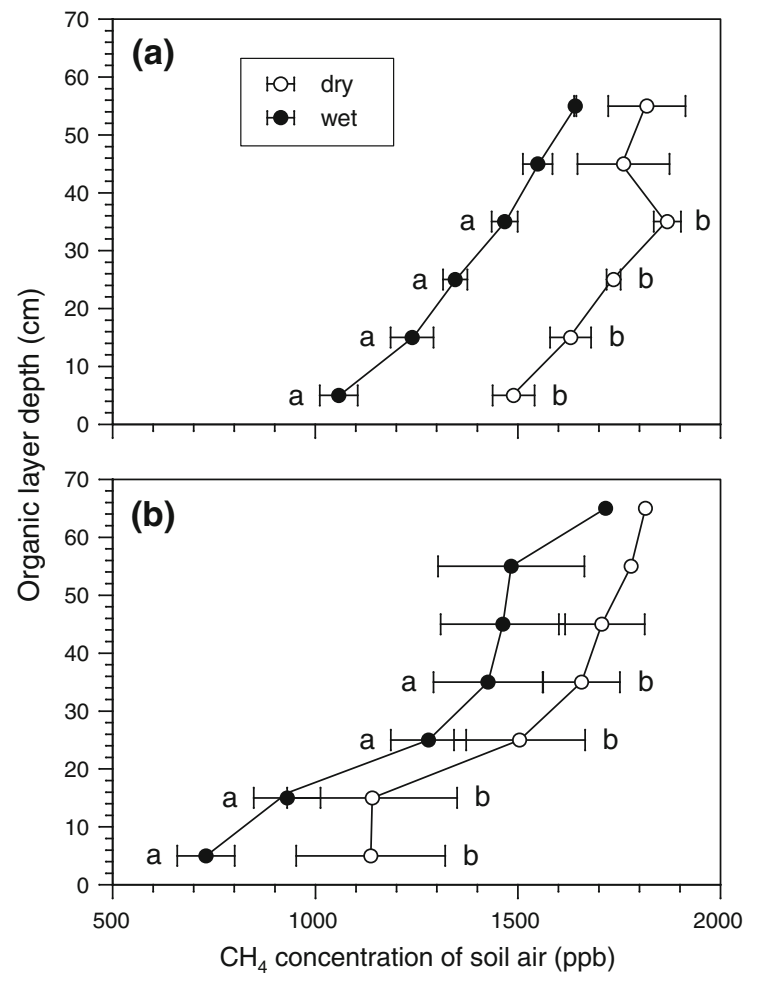

Fig. 6 Mean soil air $\mathrm{CH}_{4}$ concentrations $( \pm \mathrm{SE})$ at different depths of the organic layer during a wet period (black symbols) and a dry period (open symbols), from the a 2,000 $\mathrm{m}$ site and b the $3,000 \mathrm{~m}$ site

condition in our study area was rather limited because of the largely non-seasonal climate.

\section{$\mathrm{CH}_{4}$ fluxes and their controls}

In contrast to the general idea that soil moisture content is an important driver for $\mathrm{CH}_{4}$ fluxes (Butterbach-Bahl et al. 2004; Curry 2007; Davidson et al. 2004; Keller and Reiners 1994), neither temporal nor spatial variability of net $\mathrm{CH}_{4}$ exchange could be explained by it. The main reason for this lack of correlation between soil moisture content and net exchange of atmospheric $\mathrm{CH}_{4}$ is probably the absence of a pronounced dry season and the resulting small variation in soil moisture content. Furthermore, it is unlikely that moisture contents in the highly porous, coarse material of the upper organic layer are high enough to restrict $\mathrm{CH}_{4}$ diffusion into the soil. Our incubation of mineral soil from different geological substrates corroborates findings that coarser soil texture leads to larger potential atmospheric $\mathrm{CH}_{4}$ uptake as a result of higher gas diffusivity (Dörr et al. 1993; Saari et al. 1997). However, this texture effect did not explain the spatial variability of atmospheric $\mathrm{CH}_{4}$ uptake observed in our field measurements. We found no evidence that landscape differentiation using the geological substrate or soil texture would improve estimates of soil $\mathrm{CH}_{4}$ uptake in this region. This finding contrasts with studies in temperate forest ecosystems where soil texture was identified as a main control of soil uptake of atmospheric $\mathrm{CH}_{4}$ (Saari et al. 1997).

We found no indication that ammonium inhibition of methanotrophic bacteria was a control mechanism for $\mathrm{CH}_{4}$ uptake. On the contrary, we detected positive correlations between soil mineral $\mathrm{N}$ content and annual $\mathrm{CH}_{4}$ uptake which suggests that methanotrophic activity may have been $\mathrm{N}$ limited. This finding supports the findings of other studies carried out in several ecosystems showing lower oxidation activity due to nitrogen limitation (Aronson and Helliker 2010; Bodelier and Laanbroek 2004). Furthermore, positive correlations with $\mathrm{P}_{\text {tot }}$ content, $\mathrm{pH}$-value of the $\mathrm{Ah}$ horizon and field $\mathrm{CO}_{2}$ emissions suggest that higher $\mathrm{CH}_{4}$ uptake occurred at those locations where conditions were generally more favorable for microbial activity.

Stratification of potential uptake of atmospheric $\mathrm{CH}_{4}$ in mineral soil and organic layers

The detected stratification of atmospheric $\mathrm{CH}_{4}$ uptake in the incubated mineral soil profiles, with highest potential $\mathrm{CH}_{4}$ uptake at a soil depth of $5-10 \mathrm{~cm}$ is in agreement with findings of studies from temperate and subarctic forest soils (Schnell and King 1994). The subsurface location of maximum $\mathrm{CH}_{4}$ oxidation is probably due to edaphic factors in the surface layer, that are suboptimal or inhibitory for the growth of $\mathrm{CH}_{4}$ oxidizing bacteria, e.g. occasional droughts or the occasional occurrence of anaerobic microsites. The negative relationship between $\mathrm{CO}_{2}$ production and atmospheric $\mathrm{CH}_{4}$ consumption of our incubated soil samples, may be the result of $\mathrm{CH}_{4}$ inhibition by $\mathrm{NH}_{4}{ }^{+}$ released due to rapid $\mathrm{N}$-mineralization of organic matter during transport and pre-incubation (Arnold et al. 2008). We can, however, not exclude that this is an artifact of our incubation, as under field conditions an accumulation of $\mathrm{NH}_{4}{ }^{+}$would normally not happen due to plant uptake. In addition to inhibition by 
accumulated $\mathrm{NH}_{4}{ }^{+}$, stratification of potential $\mathrm{CH}_{4}$ uptake may also be due to the sensitivity of microorganisms to temperature and soil moisture changes, which are more pronounced in the upper organic layer than in the deeper organic layer or in the Ah horizon (Butterbach-Bahl and Papen 2002b). Finally, we also found some evidence that anaerobic microsites were created, due to high microbial activity in the uppermost organic layers leading to low methanotrophic activity.

The results of the laboratory incubations of the organic layer samples at the $1,000 \mathrm{~m}$ site appear to endorse the findings from temperate forest soils, that organic layers consume little, if any, atmospheric $\mathrm{CH}_{4}$ and that most of the $\mathrm{CH}_{4}$ uptake capacity is located in the upper mineral soil (Conrad 1996). However, the results from our incubations of the 2,000 and 3,000 m organic layers revealed substantial capacity to oxidize atmospheric $\mathrm{CH}_{4}$, with highest methanotrophic activity located in the lowest organic layers right above the mineral soil, which contained mainly strongly decomposed and humified organic matter. As the $\mathrm{CH}_{4}$ concentrations measured in the soil air were below atmospheric, we conclude that this methanotrophic activity was of the high affinity type.

\section{Conclusions}

Although we found as expected a decrease in $\mathrm{CH}_{4}$ uptake rates with increasing elevation, the widely accepted control mechanisms gas diffusivity, $\mathrm{NH}_{4}{ }^{+}$ inhibition and the creation of anaerobic microsites could not or only partly explain variations in atmospheric $\mathrm{CH}_{4}$ uptake of these tropical montane forest soils. In contrast we found some unexpected factors controlling net methane fluxes. Net methane uptake occurred mainly under conditions which are generally favorable for microbial activity, and we found indications that it was $\mathrm{N}$ limited instead of inhibited by $\mathrm{NH}_{4}{ }^{+}$. Finally, we showed that in the thick organic layers substantial high affinity methane oxidation occurred which can influence the $\mathrm{CH}_{4}$ budget of tropical montane forest soils. Inclusion of elevation as a co-variable will greatly improve regional estimates of $\mathrm{CH}_{4}$ exchange in tropical montane forests.

Acknowledgments We thank Patricio Salas, Angel Macas, Fabian Cuenca and Marco Silva for excellent field and laboratory assistance; Anke Müller and Amanda Matson for their support collecting field data; the laboratory staff of the Buesgen Institute, University of Goettingen, for their assistance in laboratory analysis; The Ministerio del Ambiente for research permits, the Nature and Culture International (NCI) in Loja for providing the study area and the research station; The Universidad Técnica Particular de Loja for cooperation; The Deutsche Forschungsgemeinschaft for funding this project as subprojects A2.4 and A2.2 (Ve219/8-1 A2.2 and Le762/10-1) of the research unit 'Biodiversity and sustainable management of a mega diverse mountain ecosystem in southern Ecuador' (FOR 816).

Open Access This article is distributed under the terms of the Creative Commons Attribution Noncommercial License which permits any noncommercial use, distribution, and reproduction in any medium, provided the original author(s) and source are credited.

\section{References}

Arnold J, Corre MD, Veldkamp E (2008) Cold storage and laboratory incubation of intact soil cores do not reflect insitu nitrogen cycling rates of tropical forest soils. Soil Biol Biochem 40:2480-2483

Arnold J, Corre MD, Veldkamp E (2009) Soil N cycling in oldgrowth forests across an Andosol toposequence in Ecuador. For Ecol Manag 257:2079-2087

Aronson EL, Helliker BR (2010) Methane flux in non-wetland soils in response to nitrogen addition: a meta-analysis. Ecology 91:3242-3251

Blake GR, Hartge KH (1986) Bulk density. In: Klute A (ed) Methods of soil analysis, part 1. Physical and mineralogical methods. Agronomy Monograph, Soil Science Society of America, Madison, pp 363-375

Bliese PD, Ployhart RE (2002) Growth modeling using random coefficient models: model building, testing, and illustrations. Organ Res Methods 5:362-387

Bodelier PLE, Laanbroek HJ (2004) Nitrogen as a regulatory factor of methane oxidation in soils and sediments. FEMS Microbiol Ecol 47:265-277

Brumme R, Borken W (1999) Site variation in methane oxidation as affected by atmospheric deposition and type of temperate forest ecosystem. Glob Biogeochem Cycles 13:493-501

Butterbach-Bahl K, Papen H (2002) Four years continuous record of $\mathrm{CH} 4$-exchange between the atmosphere and untreated and limed soil of a N-saturated spruce and beech forest ecosystem in Germany. Plant Soil 240:77-90

Butterbach-Bahl K, Rothe A, Papen H (2002) Effect of tree distance on $\mathrm{N} 2 \mathrm{O}$ and $\mathrm{CH} 4$-fluxes from soils in temperate forest ecosystems. Plant Soil 240:91-103

Butterbach-Bahl K, Kock M, Willibald G, Hewett B, Buhagiar S, Papen H, Kiese R (2004) Temporal variations of fluxes of $\mathrm{NO}, \mathrm{NO} 2, \mathrm{~N} 2 \mathrm{O}, \mathrm{CO} 2$, and $\mathrm{CH} 4$ in a tropical rain forest ecosystem. Glob Biogeochem Cycles 18(3). Article No. GB3012. doi:10.1029/2004GB002243

Conrad R (1996) Soil microorganisms as controllers of atmospheric trace gases (H-2, CO, CH4, OCS, N2O, and NO). Microbiol Rev 60:609-640 
Crawley MJ (2009) The R book. Wiley \& Sons, Chichester

Curry CL (2007) Modeling the soil consumption of atmospheric methane at the global scale. Glob Biogeochem Cycles 21:1-15

Davidson EA, Ishida FY, Nepstad DC (2004) Effects of an experimental drought on soil emissions of carbon dioxide, methane, nitrous oxide, and nitric oxide in a moist tropical forest. Glob Change Biol 10:718-730

Delmas RA, Servant J, Tathy JP, Cros B, Labat M (1992) Sources and sinks of methane and carbon-dioxide exchanges in mountain forest in Equatorial Africa. J Geophys Res 97:6169-6179

Dörr H, Katruff L, Levin I (1993) Soil texture parameterization of the methane uptake in aerated soils. Chemosphere 26:697-713

Dutaur L, Verchot LV (2007) A global inventory of the soil CH4 sink. Glob Biogeochem Cycles 21:1-9

Edwards PJ, Grubb PJ (1977) Studies of mineral cycling in a montane rain-forest in New-Guinea: 1. J Ecol 65:943-969

Emck P (2007) A climatology of south Ecuador with special focus on the major Andean ridge as Atlantic-Pacific climate divide. Naturwissenschaftliche Fakultäten. FriedrichAlexander-Universität Erlangen-Nürnberg, Erlangen-Nürnberg, p 275

Fiedler S, Höll BS, Jungkunst HF (2005) Methane budget of a Black Forest spruce ecosystem considering soil pattern. Biogeochemistry 76:1-20

Forster P, Ramaswamy V, Artaxo P, Berntsen T, Betts R, Fahey DW, Haywood J, Lean J, Lowe DC, Myhre G, Nganga J, Prinn R, Raga G, Schulz M, Dorland RV (2007) Changes in atmospheric constituents and in radiative forcing. In: Solomon S, Qin D, Manning M, Chen Z, Marquis M, Averyt KB, Tignor M, Miller HL (eds) Climate change 2007: the physical science basis. Contribution of working group I to the fourth assessment report of the Intergovernmental Panel on climate change. Cambridge University Press, Cambridge

FRA (2000) Global forest recources assessment 2000-main report. Food and Agriculture Organization of the United Nations (FAO), Rome

Ishizuka S, Iswandi A, Nakajima Y, Yonemura S, Sudo S, Tsuruta H, Murdiyarso D (2005) The variation of greenhouse gas emissions from soils of various land-use/cover types in Jambi province, Indonesia. Nutr Cycl Agroecosyst 71:17-32

Keller M, Reiners WA (1994) Soil atmosphere exchange of nitrous-oxide, nitric-oxide, and methane under secondary succession of pasture to forest in the Atlantic lowlands of Costa-Rica. Glob Biogeochem Cycles 8:399-409

Keller M, Varner R, Dias JD, Silva H, Crill P, Oliveira RC Jr, Asner AG (2005) Soil-atmosphere exchange of nitrous oxide, nitric oxide, methane, and carbon dioxide in logged and undisturbed forest in the Tapajos National Forest, Brazil. Earth Interact 9:1-28

Kiese R, Hewett B, Graham A, Butterbach-Bahl K (2003) Seasonal variability of $\mathrm{N} 2 \mathrm{O}$ emissions and $\mathrm{CH} 4$ uptake by tropical rainforest soils of Queensland, Australia. Glob Biogeochem Cycles 17:1043-1055

Kiese R, Wochele S, Butterbach-Bahl K (2008) Site specific and regional estimates of methane uptake by tropical rainforest soils in north eastern Australia. Plant Soil 309:211-226
Le Mer J, Roger P (2001) Production, oxidation, emission and consumption of methane by soils: a review. Eur J Soil Biol $37: 25-50$

Litherland M, Aspen JA, Jemielita RA (1994) The metamorphic belts of Ecuador-Overseas geology and mineral resources. British Geological Survey, Keyworth, Nottingham

Livingston GP, Hutchinson GL, Spartalian K (2006) Trace gas emission in chambers: a non-steady-state diffusion model. Soil Sci Soc Am J 70:1459-1469

Loftfield N, Flessa H, Augustin J, Beese F (1997) Automated gas chromatographic system for rapid analysis of the atmospheric trace gases methane, carbon dioxide, and nitrous oxide. J Environ Qual 26:560-564

Martinson GO, Werner FA, Scherber C, Conrad R, Corre MD, Flessa H, Wolf K, Klose M, Gradstein SR, Veldkamp E (2010) Methane emissions from tank bromeliads in neotropical forests. Nat Geosci 3:766-769. doi:710.1038/ ngeo1980

Maurer D, Kolb S, Haumaier L, Borken W (2008) Inhibition of atmospheric methane oxidation by monoterpenes in Norway spruce and European beech soils. Soil Biol Biochem 40:3014-3020

Mosier AR, Delgado JA (1997) Methane and nitrous oxide fluxes in grasslands in western Puerto Rico. Chemosphere 35:2059-2082

Piepho HP, Büchse A, Richter C (2004) A mixed modelling approach for randomized experiments with repeated measures. J Agron Crop Sci 190:230-247

Potter CS, Davidson EA, Verchot LV (1996) Estimation of global biogeochemical controls and seasonality in soil methane consumption. Chemosphere 32:2219-2246

Prather M, Ehhalt D, Dentener F, Derwent R, Dlugokencky E, Holland E, Isaksen I, Katima J, Kirchhoff V, Matson P, Midgley P, Wang M (2001) Atmospheric chemistry and greenhouse gases. In: Houghton JT, Ding Y, Griggs DJ, Noguer M, van der Linden PJ, Dai X, Maskell K, Johnson CA (eds) Climate change 2001: the scientific basis. Contribution of working group I to the third assessment report of the intergovernmental panel on climate change. Cambridge University Press, Cambridge, p 239

Purbopuspito J, Veldkamp E, Brumme R, Murdiyarso D (2006) Trace gas fluxes and nitrogen cycling along an elevation sequence of tropical montane forests in Central Sulawesi, Indonesia. Glob Biogeochem Cycles 20:GB3010

R Development Core Team (2009) R: a language and environment for statistical computing. R Foundation for Statistical Computing, Vienna

Reiners WA, Keller M, Gerow KG (1998) Estimating rainy season nitrous oxide and methane fluxes across forest and pasture landscapes in Costa Rica. Water Air Soil Pollut 105:117-130

Saari A, Martikainen PJ, Ferm A, Ruuskanen J, De Boer W, Troelstra SR, Laanbroek HJ (1997) Methane oxidation in soil profiles of Dutch and Finnish coniferous forests with different soil texture and atmospheric nitrogen deposition. Soil Biol Biochem 29:1625-1632

Saari A, Heiskanen J, Martikainen PJ (1998) Effect of the organic horizon on methane oxidation and uptake in soil of a boreal Scots pine forest. FEMS Microbiol Ecol 26:245-255 
Schlichting E, Blume HP, Stahr K (1995) Bodenkundliches Praktikum. Blackwell, Berlin

Schnell S, King GM (1994) Mechanistic analysis of ammonium inhibition of atmospheric methane consumption in forest soils. Appl Environ Microbiol 60:3514-3521

Smith KA, Dobbie KE, Ball BC, Bakken LR, Sitaula BK, Hansen S, Brumme R, Borken W, Christensen S, Prieme A, Fowler D, Macdonald JA, Skiba U, Klemedtsson L, Kasimir-Klemedtsson A, Degorska A, Orlanski P (2000) Oxidation of atmospheric methane in Northern European soils, comparison with other ecosystems, and uncertainties in the global terrestrial sink. Glob Change Biol 6:791-803

Steinkamp R, Butterbach-Bahl K, Papen H (2001) Methane oxidation by soils of an $\mathrm{N}$ limited and $\mathrm{N}$ fertilized spruce forest in the Black Forest, Germany. Soil Biol Biochem 33:145-153

Striegl RG (1993) Diffusional limits to the consumption of atmospheric methane by soils. Chemosphere 26:715-720

Topp E, Pattey E (1997) Soils as sources and sinks for atmospheric methane. Can J Soil Sci 77:167-178
Veldkamp E, Weitz AM, Keller M (2001) Management effects on methane fluxes in humid tropical pasture soils. Soil Biol Biochem 33:1493-1499

Verchot LV, Davidson EA, Cattanio JH, Ackerman IL (2000) Land-use change and biogeochemical controls of methane fluxes in soils of eastern Amazonia. Ecosystems 3:41-56

Wagner SW, Reicosky DC, Alessi RS (1997) Regression models for calculating gas fluxes measured with a closed chamber. Agron J 89:279-284

Werner C, Zheng XH, Tang JW, Xie BH, Liu CY, Kiese R, Butterbach-Bahl K (2006) N2O, CH4 and CO2 emissions from seasonal tropical rainforests and a rubber plantation in Southwest China. Plant Soil 289:335-353

Wolf K, Veldkamp E, Homeier J, Martinson GO (2011) Nitrogen availability links forest productivity, soil nitrous oxide and nitric oxide fluxes of a tropical montane forest in southern Ecuador. Glob Boigeochem Cycles. doi: 10.1029/2010GB003876 